\title{
Synergistic cytotoxic effects of arsenite and tetrandrine in human breast cancer cell line MCF-7
}

\author{
MINGJIANG YAO ${ }^{1,4^{*}}$, BO YUAN ${ }^{1,2^{*}}$, XIAO WANG $^{1}$, AI SATO $^{2}$, KANA SAKUMA $^{1}$, \\ KURUMI KANEKO $^{1}$, HANA KOMURO ${ }^{1}$, AYANE OKAZAKI ${ }^{1}$, HIDEKI HAYASHI ${ }^{1}$, \\ HIROO TOYODA ${ }^{2}$, XIAOHUA PEI $^{5}$, XIAOMEI HU ${ }^{4}$, TOSHIHIKO HIRANO ${ }^{3}$ and NORIO TAKAGI ${ }^{1}$ \\ Departments of ${ }^{1}$ Applied Biochemistry, ${ }^{2}$ Clinical Molecular Genetics and ${ }^{3}$ Clinical Pharmacology, \\ School of Pharmacy, Tokyo University of Pharmacy and Life Sciences, Hachioji, Tokyo 192-0392, Japan; \\ ${ }^{4}$ Xiyuan Hospital, China Academy of Chinese Medical Sciences, Beijing 100091 ; ${ }^{5}$ The Third Affiliated Hospital \\ of Beijing University of Traditional Chinese Medicine, Beijing 100029, P.R. China
}

Received April 17, 2017; Accepted May 29, 2017

DOI: $10.3892 /$ ijo.2017.4052

\begin{abstract}
To provide novel insight into the development of new therapeutic strategies to combat breast cancer using trivalent arsenic (As ${ }^{\mathrm{III}}$ )-based combination therapy, the cytotoxicity of a combination of $\mathrm{As}{ }^{\mathrm{III}}$ and tetrandrine (Tetra), a Chinese plant-derived alkaloid, was investigated in the human breast cancer cell line MCF-7. Cytotoxicity was evaluated using cell viability, colony formation, wound healing, lactate dehydrogenase leakage and cell cycle assay. Alterations of genes associated with cell proliferation and death were analyzed using real-time PCR and western blotting. Intracellular arsenic accumulation (As[i]) was also determined. Tetra significantly enhanced the cytotoxicity of $\mathrm{As}^{\mathrm{III}}$ in MCF-7 cells in a synergistic manner. The combined treatment upregulated the expression level of FOXO3a, and subsequently resulted in a concomitant increase in the expression levels of p21, p27,
\end{abstract}

Correspondence to: Dr Bo Yuan, Department of Applied Biochemistry, School of Pharmacy, Tokyo University of Pharmacy and Life Sciences, 1432-1 Horinouchi, Hachioji, Tokyo 192-0392, Japan

E-mail: yuanbo@toyaku.ac.jp

*Contributed equally

Abbreviations: As ${ }^{\mathrm{III}}$, trivalent arsenic (arsenite); Tetra, tetrandrine; p21, p21 Waf1/Cip1; p27, p27 Kip1; FOXO3a, forkhead box transcription factor $3 \mathrm{a}$; ABC transporters, ATP-binding cassette transporters; MRP1, ABCC1/multidrug resistance-associated protein 1; MDR1, ABCB1/multidrug resistance 1; BCRP, ABCG2/ breast cancer resistance protein; $\mathrm{CI}$, combination index; $\mathrm{LDH}$, lactate dehydrogenase; As[i], intracellular arsenic accumulation; ICP-MS, inductively coupled plasma-mass spectrometry; phospho-AMPK, phosphorylated AMP-activated protein kinase; phospho-mTOR, phosphorylated mammalian target of rapamycin

Key words: arsenite, tetrandrine, MCF-7 cell, cell cycle arrest, autophagy induction, necrotic cell death, combination therapy and decrease of cycline D1, which occurred in parallel with $\mathrm{G}_{0} / \mathrm{G}_{1}$ phase arrest. Autophagy induction was also observed in the combination treatment. Importantly, combining As ${ }^{\mathrm{III}}$ with Tetra exhibited a synergistic inhibitory effect on the expression level of survivin. Furthermore, enhanced As[i] along with synergistic cytotoxicity was observed in MCF-7 cells treated with $\mathrm{As}{ }^{\mathrm{III}}$ combined with Tetra or Ko134, an inhibitor of breast cancer resistance protein (BCRP), suggesting that Tetra or the BCRP inhibitor probably intervened in the occurrence of resistance to arsenic therapy by enhancing the As[i] via modulation of multidrug efflux transporters. These results may provide a rational molecular basis for the combination regimen of $A s^{\mathrm{III}}$ plus Tetra, facilitating the development of $\mathrm{As}^{\mathrm{III}}$-based anticancer strategies and combination therapies for patients with solid tumors, especially breast cancer.

\section{Introduction}

Breast cancer is the most common cancer among women worldwide and persists as one of the leading causes of cancer-related deaths despite advances in early detection, diagnosis, and targeted treatment options such as Herceptin (trastuzumab) $(1,2)$. The need for novel therapeutic strategies remains paramount given the sustained development of drug resistance, tumor recurrence, and metastasis $(1,2)$. In this regard, the successful clinical efficacy of arsenic trioxide $\left(\mathrm{As}_{2} \mathrm{O}_{3}\right.$, a trivalent arsenic derivative) in the treatment of acute promyelocytic leukemia (APL) has resulted in further investigations exploring its potential treatment application for other malignancies, including solid tumors $(3,4)$. Trivalent arsenic (arsenite, As ${ }^{\mathrm{III}}$ ) has been demonstrated to exhibit inhibitory effects against breast cancer cells (5-7), raising the possibility of utilizing arsenic compounds to treat patients with breast cancer. The side effects of $\mathrm{As}^{\mathrm{III}}$, in particular, As ${ }^{\mathrm{III}}$-mediated QT prolongation, remain a serious concern limiting its clinical application. Solid tumors, including breast cancer, also demonstrate a lower susceptibility to arsenic compounds (8-10). Therefore, a growing need exists to create new approaches aimed at improving its efficiency and reducing its side effects. 
Tetrandrine (Tetra), a bis-benzylisoquinoline alkaloid isolated from the root of Stephania tetrandra S Moore, has a long history in Chinese medicine treating diverse diseases such as silicosis, inflammatory pulmonary diseases, and hypertension (11). Furthermore, Tetra has been demonstrated to not only possess the capacity to inhibit the growth of several different types of cancer cell lines, but also show a potential for increasing the efficacy of chemotherapy drugs in combined treatment (12-14). These previous findings suggest that Tetra may serve as a promising adjuvant to enhance the efficacy of conventional anticancer drugs. While Tetra has been shown to enhance the cytotoxicity of As ${ }^{\text {III }}$ in HepG2 (human hepatoma cell line) and A549 (human lung carcinoma cell line) (13), the effects of combining As ${ }^{\mathrm{III}}$ and Tetra against breast cancer cells have yet to be evaluated.

Cell cycle arrest, necrosis, as well as autophagic cell death have been viewed as the major underlying mechanisms for the cytocidal effects of most chemotherapeutic drugs $(7,13,15-18)$. The cell cycle is a complex process that is precisely regulated by vital molecules known as cyclin-dependent kinases (CDKs) and CDK inhibitors such as p21 Waf1/Cip1 (p21) and p27 Kip1 (p27) $(7,19,20)$. Of note, forkhead box transcription factor (FOXO3a), which is considered to be involved in the development of breast cancer and may also serve as a prognostic marker in breast cancer (21), has been implicated in the control of genes involving multiple cellular processes, including cell cycle, migration, invasion, and cell death (2,20-24). Survivin, another important cancer-associated protein that is highly expressed in most human tumors, is similarly known to participate in the above cellular processes (25-28). However, whether and how these molecules contribute to the potential cytotoxic effects induced by a combination of $\mathrm{As}^{\mathrm{III}}$ and Tetra against breast cancer cells remain to be seen.

In the clinical treatment of cancer, combination therapy has been widely recognized to decrease cell viability and clonogenic growth, and reduce toxicity, although sequential chemotherapy remains the standard of care for a variety of malignancies including breast cancer (29). In this regard, previous reports $(30,31)$ have revealed that Tetra enhances cytotoxicity of conventional anticancer drugs such as cisplatin, daunorubicin and doxorubicin by inhibition of some ATP-binding cassette (ABC) transporters including $\mathrm{ABCC} 1 /$ multidrug resistance-associated protein 1 (MRP1) and $\mathrm{ABCB} 1 /$ multidrug resistance 1 (MDR1), all of which are known to mediate drug efflux and play a prominent role in the chemoresistance to several cytotoxic agents including arsenic compounds (3). These previous findings suggest that Tetra may be a promising candidate for combination chemotherapy regimens through the manipulation of drug efflux transporters thereby enhancing the efficacy of anticancer drugs. Although treatment with $\mathrm{As}_{2} \mathrm{~S}_{2}$ dramatically increases the expression of $\mathrm{ABCG}$ /breast cancer resistance protein (BCRP), another important multidrug resistance-conferring $\mathrm{ABC}$ transporter, in a myeloid leukemia cell line K562 (32), the relevance of BCRP to arsenic compound-mediated cytotoxicity as well as arsenic resistance is not known.

In this study, in order to provide novel insight into the development of new therapeutic strategies to combat breast cancer using $\mathrm{As}^{\mathrm{III}}$-based combination therapy, the cytotoxicity of a combination of sodium arsenite (another trivalent arsenic compound) and Tetra was investigated in the human breast cancer cell line MCF-7 by focusing on cell cycle arrest, necrosis, and autophagic cell death. Key regulatory molecules associated with the cell cycle and death were investigated to further elucidate cytotoxic mechanisms. Intracellular arsenic accumulation (As[i]) was also evaluated in order to clarify the contribution of multidrug efflux transporters including BCRP to cytotoxicity.

\section{Materials and methods}

Materials. Sodium arsenite $\left(\mathrm{NaAsO}_{2}, \mathrm{As}^{\mathrm{III}}\right)$ and tetrandrine (Tetra) were purchased from Tri Chemical Laboratories (Yamanashi, Japan) and National Institutes for Food and Drug Control (Beijing, China), respectively. Fetal bovine serum (FBS) was purchased from Nichirei Biosciences (Tokyo, Japan). RPMI-1640 medium, phenazine methosulfate (PMS), dimethyl sulfoxide (DMSO) and Giemsa stain solution were obtained from Wako Pure Chemical Industries (Osaka, Japan). Propidium iodide (PI), ribonuclease A (RNaseA), and 2,3-bis(2-methoxy-4-nitro-5-sulfophenyl)-5-[(phenylamino) carbony] $-2 H$-tetrazolium hydroxide (XTT) were purchased from Sigma-Aldrich (St. Louis, MO, USA). Ko134, an inhibitor of BCRP, was obtained from Solvo Biotechnology (Kyoto, Japan). ReverTra Ace qPCR RT Master Mix with gDNA Remover, Thunderbird SYBR qPCR Mix, RNase inhibitor, Can Get Signal ${ }^{\circledR}$ Immunoreaction Enhancer Solution were purchased from Toyobo Co., Ltd. (Osaka, Japan).

Cell culture and treatment. MCF-7 human breast adenocarcinoma cells were obtained from the RIKEN Cell Bank (Ibaraki, Japan). Cells were cultured in RPMI-1640 medium supplemented with $10 \%$ heat-inactivated FBS and $100 \mathrm{U} / \mathrm{ml}$ of penicillin and $100 \mu \mathrm{g} / \mathrm{ml}$ of streptomycin in a humidified $5 \% \mathrm{CO}_{2}$ atmosphere at $37^{\circ} \mathrm{C}$. Cells were treated with $\mathrm{As}^{\mathrm{III}}$ and Tetra, alone or in combination, in the presence or absence of BCRP inhibitor Ko134 at the indicated concentrations. Tetra was dissolved in DMSO, and no cytotoxicity of the final concentrations of DMSO was observed in the current experimental system.

Cell viability and clonogenic survival. After treatment with various concentrations of As ${ }^{\mathrm{III}}$ and Tetra, alone or in combination, for $48 \mathrm{~h}$, cell viability was measured by the XTT assay as previously described (33). The relative cell viability was expressed as the ratio of the absorbance of each treatment group against those of the corresponding untreated control group. The $\mathrm{IC}_{50}$ values of $\mathrm{As}^{\mathrm{III}}$ were calculated using GraphPad Prism $^{\circledast} 6$ software. In order to evaluate whether the two drugs generated synergistic, antagonistic, or additive effects, a combination index (CI) was determined as reported previously, using the computer software ComboSyn (ComboSyn Inc. Paramus, NJ, USA) for drug combinations and for general dose-effect analysis, which was developed by Chou $(34,35)$. The effect of the combination treatment was defined as a synergistic effect if $\mathrm{CI}<1$, an additive effect if $\mathrm{CI}=1$ or an antagonistic effect if CI $>1(13,19)$. For clonogenic survival assays, MCF-7 cells were seeded at 500 cells/well in 12-well plates, followed by the treatment with indicated concentrations of As ${ }^{\mathrm{III}}$ and Terta, alone or in combination, for $24 \mathrm{~h}$. The medium was then replaced with 
fresh media and the cells were allowed to grow for 8-12 days in a humidified $5 \% \mathrm{CO}_{2}$ atmosphere at $37^{\circ} \mathrm{C}$ before staining with Giemsa stain solution.

Wound healing assay. Cell migration was evaluated using an in vitro wound scratching assay as previously described (36). Briefly, MCF-7 cells were seeded at a density of $1 \times 10^{5}$ cells $/ \mathrm{ml}$ in 24-well plates and allowed to form a confluent monolayer. The layer of cells was scraped with a 20-200 $\mu \mathrm{l}$ micropipette tip to create a wound of approximately $0.5 \mathrm{~mm}$ in width, and then the cells were gently rinsed twice by PBS, followed by treatment with the indicated concentrations of $\mathrm{As}^{\mathrm{III}}$ and Tetra, alone or in combination, for $48 \mathrm{~h}$. The cells were photographed at 0 and $48 \mathrm{~h}$ using an inverted microscope (CK2, Olympus, Tokyo, Japan) fitted with a digital camera WRAYCAM-NF300 (Osaka, Japan). The distance between the edges of the cell-free areas was measured and the cell migration was calculated using the following equation: $\% \mathrm{R}=\left[1\right.$-(wound length at $\mathrm{T}_{48 \mathrm{~h}} /$ wound length at $\left.\left.\mathrm{T}_{0 \mathrm{~h}}\right)\right] \mathrm{x} 100 \%$ where $\% \mathrm{R}$ is the percent recovery, $\mathrm{T}_{0 \mathrm{~h}}$ is the wound length at $0 \mathrm{~h}$, and $\mathrm{T}_{48 \mathrm{~h}}$ is the wound length at $48 \mathrm{~h}$ after injury.

Cell cycle analysis. After treatment with the indicated concentrations of $\mathrm{As}^{\mathrm{III}}$ and Tetra, alone or in combination, for $48 \mathrm{~h}$, cell cycle analysis was performed using a FACSCanto flow cytometer (Becton Dickinson, San Jose, CA, USA) according to a method previously reported (37). Briefly, cells were washed twice with phosphate-buffered saline (PBS), fixed with $1 \%$ paraformaldehyde/PBS for $30 \mathrm{~min}$, washed twice again with PBS, permeabilized in $70 \%(\mathrm{v} / \mathrm{v})$ cold ethanol and kept at $-20^{\circ} \mathrm{C}$ for at least $4 \mathrm{~h}$. Cell pellets were then washed twice with PBS after centrifugation and incubated with $0.25 \%$ Triton-X 100 for $5 \mathrm{~min}$ on ice. After centrifugation and washing with PBS, cells were resuspended in $500 \mu \mathrm{l}$ of PI/RNase A/PBS $(5 \mu \mathrm{g} / \mathrm{ml}$ of PI and $0.1 \%$ RNase A in PBS) and incubated for $30 \mathrm{~min}$ in the dark at room temperature. A total of 10,000 events were acquired and Diva software and ModFit LT ${ }^{\text {тм }}$ Ver.3.0 (Verity Software House, Topsham, ME, USA) were used to calculate the number of cells at each $\mathrm{G}_{0} / \mathrm{G}_{1}$ and $\mathrm{S}$ phase fraction.

Lactate dehydrogenase $(L D H)$ assay. After treatment with the indicated concentrations of $\mathrm{As}^{\mathrm{III}}$ and Tetra, alone or in combination, for 48 and $72 \mathrm{~h}$, LDH leakage from cells was measured using the LDH-Cytotoxic Test Wako kit (Wako Pure Chemical Industries) according to the method previously described with slight modifications $(15,33)$. Briefly, culture supernatants were collected by centrifugation at 2,500 rpm for 5 min at $4^{\circ} \mathrm{C}$. Non-treated cells were lysed in culture medium containing $0.2 \%$ Tween-20, and mixed aggressively using a vortex mixer, followed by the centrifugation at $12,000 \mathrm{x} \mathrm{g}$ for $10 \mathrm{~min}$ and the cell lysate was used as the positive control. Culture medium served as the negative control. Culture supernatants were collected then diluted 16-fold with PBS and $50 \mu \mathrm{l}$ of the diluted solution was transferred into wells of a 96-well plate. LDH activities were determined by adding $50 \mu 1$ of 'substrate solution' from the kit, followed by incubation at room temperature for $30 \mathrm{~min}$. The reaction was stopped by the addition of $100 \mu \mathrm{l}$ of 'stopping solution' and the absorbance at $560 \mathrm{~nm}$ was measured with a microplate reader (Safire, Tecan, Switzerland). Cell damage was calculated as a percentage of
LDH leakage from damaged cells using the following formula: LDH leakage $(\%)=($ Sup-NC) $/(\mathrm{P}-\mathrm{NCT}) \times 100$ where Sup, NC, $\mathrm{P}$ and NCT refer to the absorption of the culture supernatant, negative control, positive control and culture medium containing $0.2 \%$ Tween-20, respectively.

$R N A$ extraction, reverse transcription $(R T)$, and real-time $P C R$. Total RNA isolation and complementary DNA were prepared according to a method previously reported with modifications $(33,38)$. Briefly, total RNA was extracted from cells using an RNA extraction kit, Isogen II (Nippon Gene, Tokyo, Japan) and quantified by BioSpec-nano (Shimazu Corp., Kyoto, Japan). Complementary DNA was synthesized from 500 ng of RNA using ReverTra Ace ${ }^{\circledR}$ qPCR RT Master Mix with gDNA Remover according to the manufacturer's protocol. Real time RT-PCR assay was performed using the CFX Connect (Bio-Rad Laboratories, Hercules, CA, USA) thermal cycler detection system. DNA primers for real-time PCR were purchased from Sigma-Aldrich (Tokyo, Japan) using the forward primer (5'-ccagatgacgaccccatagag-3') and reverse primer (5'-ttgttggtttcctttgcaatttt-3') for survivin (GenBank accession no.: NM_001168) (39); and the forward primer (5'-catccetgcetctactggcg-3') and reverse primer (5'-agcttcccgttcagctcagg-3') for glyceraldehyde-3-phosphate dehydrogenase (GAPDH) (GenBank accession no.: NM_002046.3) served as a housekeeping gene. Thermal cycling conditions consisted of $10 \mathrm{sec}$ denaturation at $95^{\circ} \mathrm{C}$, $15 \mathrm{sec}$ annealing at $60^{\circ} \mathrm{C}$, and $20 \mathrm{sec}$ primer extension at $70^{\circ} \mathrm{C}$, and 45 cycles were conducted. A 1-min activation step preceded cycling $\left(95^{\circ} \mathrm{C}\right)$. A fold change in relative expression of survivin was calculated based on the comparative $\mathrm{Ct}\left(2^{-\Delta \Delta \mathrm{Ct}}\right)$ method. Analysis of melting curves was applied to confirm whether all PCR products are single.

Western blot analysis. Western blot analysis was carried out according to the methods previously described (40). Briefly, after separation of proteins on a sodium dodecyl sulfate (SDS) polyacrylamide gel electrophoresis, followed by transferring to a polyvinylidene difluoride (PVDF) membrane (Millipore Corp., Bedford, MA, USA), protein bands were detected using the following primary antibodies and dilution ratios: mouse anti-human $\beta$-actin (1:5,000 dilution, Sigma-Aldrich, St. Louis MO, USA); rabbit anti-human FOXO3a (1:1,000 dilution), rabbit anti-human p27 (1:1,000 dilution), mouse anti-human p21 (1:1,000 dilution), rabbit anti-human cyclin D1 (1:1,000 dilution), mouse anti-human survivin (1:1000 dilution), rabbit anti-human phospho-AMPK $\alpha 1$ (Ser485) and AMPK $\alpha$ (1:1,000 dilution), rabbit anti-human phospho-mTOR (Ser2448) and mTOR (1:1,000 dilution), rabbit anti-human Beclin-1 (1:1,000 dilution), rabbit anti-human Atg7 (1:1,000 dilution), rabbit anti-human LC3 (1:1,000 dilution) (Cell Signaling Technology, Danvers, MA, USA). Blotted protein bands were detected with respective horseradish peroxidase-conjugated secondary antibody and an enhanced chemiluminescence (ECL) Western blot analysis system (Amersham Pharmacia Biotech, Buckinghamshire, UK).

Analysis of intracellular arsenic accumulation (As[i]). After exposure of MCF-7 cells to $3 \mu \mathrm{M}$ As ${ }^{\mathrm{III}}$ alone or in combination with $1 \mu \mathrm{g} / \mathrm{ml}$ Tetra or $2 \mu \mathrm{M}$ BCRP inhibitor Ko134 for 
A

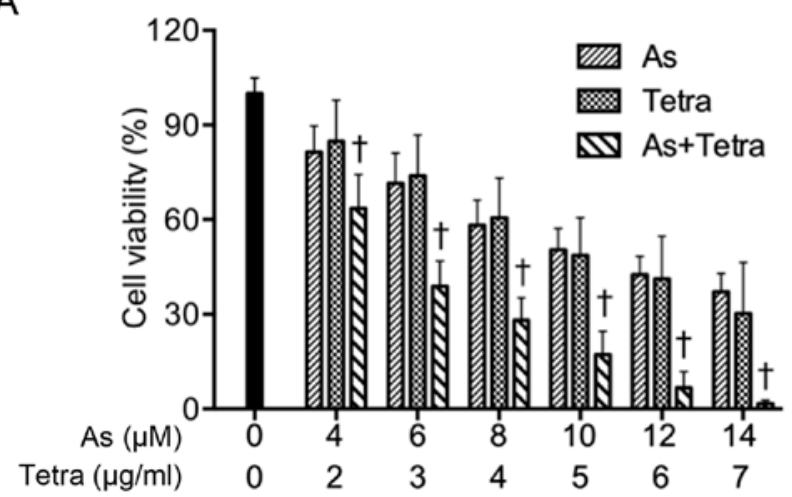

B

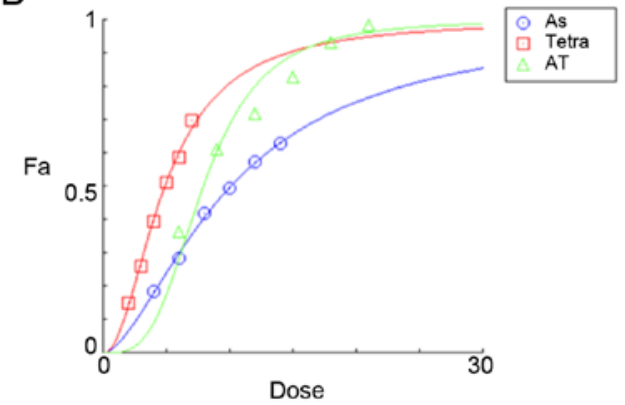

C

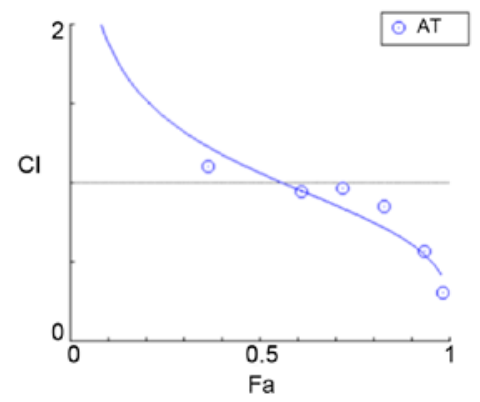

Figure 1. Synergistic cytotoxic effect of $\mathrm{As}^{\mathrm{III}}$ and Tetra in human breast cancer cell line MCF-7. (A) Cell viability was determined by XTT assay after the treatment with various concentrations of $\mathrm{As}^{\mathrm{III}}$ alone $(4,6,8,10,12$ and $14 \mu \mathrm{M})$, Tetra alone $(2,3,4,5,6$ and $7 \mu \mathrm{g} / \mathrm{ml})$, or their combination for $48 \mathrm{~h}$. Relative cell viability was calculated as the ratio of the absorbance at $450 \mathrm{~nm}$ of each treatment group against those of the corresponding untreated control group. Data are shown as the means \pm SD ( $n=3)$. ${ }^{\dagger} \mathrm{P}<0.05$ vs. each alone. (B and C) Combination of As ${ }^{\mathrm{III}}$ and Tetra exerts synergic effects on MCF-7 cells, as reflected by the median-effect method of Ting-Chao Chou. The dose-effect curves of single or combined drug treatment analyzed by the median-effect method demonstrated that the values of combination index (CI) were <1, indicating that the two drugs performed in a synergistic manner. As, As ${ }^{\mathrm{III}}$; Tetra, tetrandrine, AT, $\mathrm{As}^{\mathrm{III}}+$ tetrandrine.

$0,1,2,4,8 \mathrm{~h}$, the cells were gently washed three times with PBS and harvested in $2 \%$ SDS solution. Protein concentrations were determined by Bradford's method using the protein assay dye reagent (Bio-Rad Laboratories) according to the manufacturer's instructions, and using BSA as the standard. The quantitation of As[i] was performed by external calibration. Concentrations of As[i] were calculated from calibration curve of standard arsenic compounds. The As[i] was normalized by the amount of proteins and reported as parts per billion (ppb) of arsenic per $\mathrm{mg}$ of proteins. The analysis of total arsenic was performed by inductively coupled plasma-mass spectrometry (ICP-MS) (Perkin-Elmer Sciex, Thornhill, ON, Canada) according to the methods previously reported $(17,33,41)$.

Statistical analysis. Experiments were independently repeated three times, and reported as the means \pm standard deviation (SD) of the three assays. Statistical analysis was conducted using one-way ANOVA followed by Dunnett's post-test. A probability level of $\mathrm{P}<0.05$ was considered to indicate a statistically significant difference.

\section{Results}

Synergistic cytotoxic effect of As ${ }^{I I I}$ and Tetra in human breast cancer cell line MCF-7. A significant decrease in cell viability was observed in a dose-dependent manner in MCF-7 cells after treatment with various concentrations of
Table I. CI values of $\mathrm{As}^{\mathrm{III}}$ at concentrations in combination with Tetra in MCF-7 cells.

\begin{tabular}{cccc}
\hline As $(\mu \mathrm{M})$ & Tetra $(\mu \mathrm{g} / \mathrm{ml})$ & Fa & CI value \\
\hline 4 & 2 & 0.36365 & 1.10171 \\
6 & 3 & 0.61133 & 0.94380 \\
8 & 4 & 0.71851 & 0.96387 \\
10 & 5 & 0.82821 & 0.84989 \\
12 & 6 & 0.93335 & 0.56980 \\
14 & 7 & 0.98316 & 0.30671
\end{tabular}

The dose-effect curves of single or combined drug treatment analyzed by the median-effect method demonstrated that the values of combination index $(\mathrm{CI})$ were $<1$, indicating that the two drugs performed in a synergistic manner. $\mathrm{CI}<1$ represents synergism. As, As ${ }^{\text {III; }}$ Tetra, tetrandrine; Fa, the effect levels; CI, combination index.

As ${ }^{\mathrm{III}}$ or Tetra alone for $48 \mathrm{~h}$ (Fig. 1A), and the $\mathrm{IC}_{50}$ values were $6.1 \pm 0.9 \mu \mathrm{M}$ and $3.5 \pm 0.6 \mu \mathrm{g} / \mathrm{ml}$ for $\mathrm{As}^{\mathrm{III}}$ and Tetra treatment, respectively. In order to evaluate if the two drugs generated synergistic, antagonistic, or additive effects, based upon the above-described $\mathrm{IC}_{50}$ values, the two-drug combination in constant ratio was determined according to the median-effect method of Chou $(34,35)$. As shown in Fig. 1A, combination 


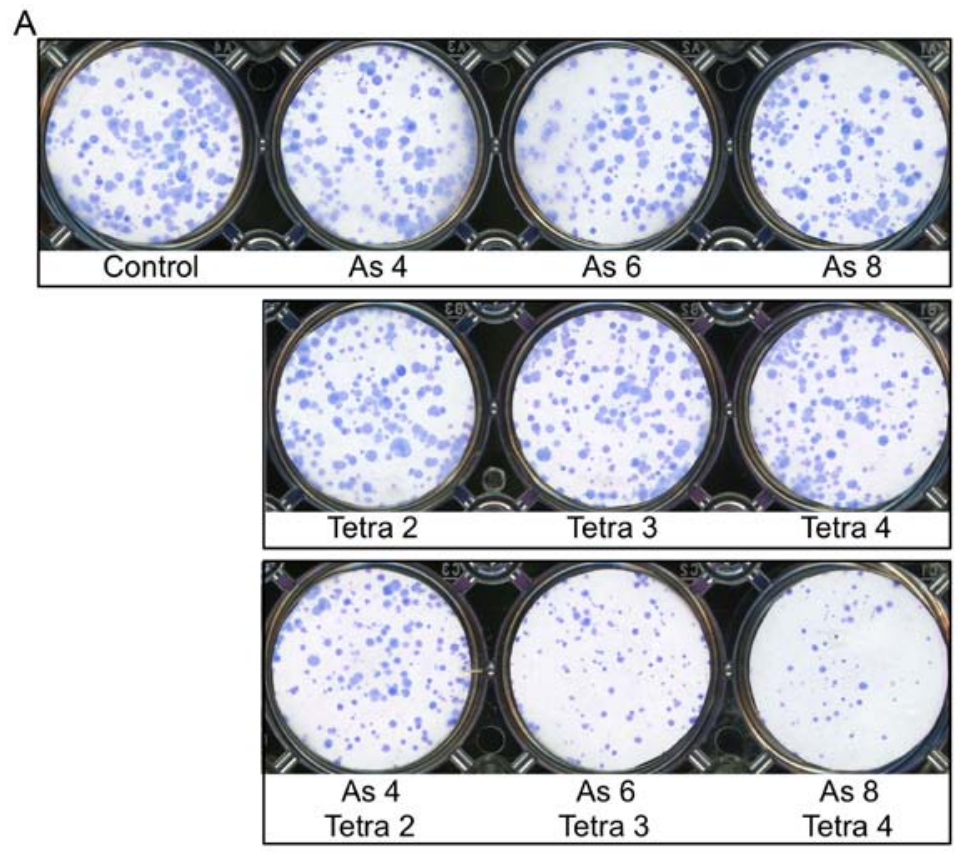

B

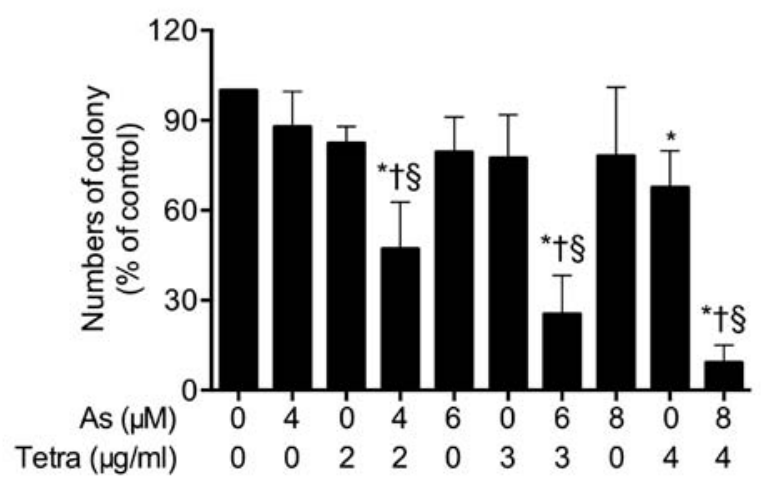

Figure 2. Inhibition of colony formation of MCF-7 cells by As ${ }^{\mathrm{III}}$ in combination with Tetra. The cells were seeded at 500 cells/well in 12 -well plates following treatment with indicated concentrations of $\mathrm{As}^{\mathrm{III}}(4,6$ and $8 \mu \mathrm{M})$ and Terta $(2,3$ and $4 \mu \mathrm{g} / \mathrm{ml})$, alone or in combination, for $24 \mathrm{~h}$. (A) Representative images of the clonogenic assays are shown from three independent experiments. (B) The numbers of colonies after treatment with $\mathrm{As}^{\mathrm{III}}$ alone or in combination with Tetra are presented. Experiments were repeated independently at least three times and results are shown as the means $\pm \mathrm{SD}$. " $\mathrm{P}<0.05$ vs. control; ${ }^{\dagger} \mathrm{P}<0.05 \mathrm{vs}$. $\mathrm{As}^{\mathrm{III}}$ alone; ${ }^{\$} \mathrm{P}<0.05$ vs. Tetra alone. As, As ${ }^{\mathrm{III}}$; Tetra, tetrandrine.

treatment was significantly more cytotoxic than either drug alone $(\mathrm{p}<0.05)$. Furthermore, the dose-effect curves of single or combined drug treatment analyzed by the median-effect method demonstrated that the values of combination index (CI) were $<1$, except for the combination of $4 \mu \mathrm{M} \mathrm{As}{ }^{\mathrm{III}}$ with $2 \mu \mathrm{g} / \mathrm{ml}$ Tetra (Fig. 1B and C, Table I), indicating that the two drugs performed in a synergistic manner.

Inhibition of colony formation of MCF-7 cells by As ${ }^{I I I}$ in combination with Tetra. To explore whether exposure to $\mathrm{As}^{\mathrm{III}}$ alone or in combination with Tetra suppressed the surviving fraction of MCF-7 cells, a colony formation assay was applied. As shown in Fig. 2, long-term treatment with $\mathrm{As}^{\mathrm{III}}$ combined with Tetra significantly suppressed the colony numbers of MCF-7 cells by 52.8, 74.6 and $90.8 \%$ for the combination of $4 \mu \mathrm{M} \mathrm{As}{ }^{\mathrm{III}}+2 \mu \mathrm{g} / \mathrm{ml}$ Tetra, $6 \mu \mathrm{M} \mathrm{As}^{\mathrm{III}}+$ $3 \mu \mathrm{g} / \mathrm{ml}$ Tetra, and $8 \mu \mathrm{M} \mathrm{As} \mathrm{s}^{\mathrm{III}}+4 \mu \mathrm{g} / \mathrm{ml}$ Tetra, respectively, confirming the synergistic cytotoxic effect of $\mathrm{As}^{\mathrm{III}}$ and Tetra against the cells.
Inhibition of the migration ability of MCF-7 cells by As ${ }^{I I I}$ in combination with Tetra. To test the effect of As ${ }^{\mathrm{II}}$ and Tetra, alone or in combination, on the proliferation and migration of MCF-7 cells, a scratch wound healing assay was conducted. Confluent monolayers of MCF-7 cells were scraped with a 20-200 $\mu 1$ micropipette tip to create a gap as shown in Fig. 3A $(0 \mathrm{~h})$, followed by the treatment with indicated concentrations of $\mathrm{As}^{\mathrm{III}}$ and Tetra, alone or in combination. As shown in Fig. 3B, after $48 \mathrm{~h}$ incubation, the gaps that remained unfilled by the migrated cells in the treated groups were wider than that in the untreated group. Furthermore, compared to groups treated with either $\mathrm{As}^{\mathrm{III}}$ or Tetra alone, combinatorial treatment effectively reduced the migration of MCF-7 cells into the wounded area, although there was no significant difference between the treatment of $6 \mu \mathrm{M} \mathrm{As}{ }^{\mathrm{III}}+3 \mu \mathrm{g} / \mathrm{ml}$ Tetra or each alone (Fig. 3C).

Effects of As ${ }^{I I I}$ and Tetra, alone or in combination, on the cell cycle profiling and the expression level of cell cycle 
A

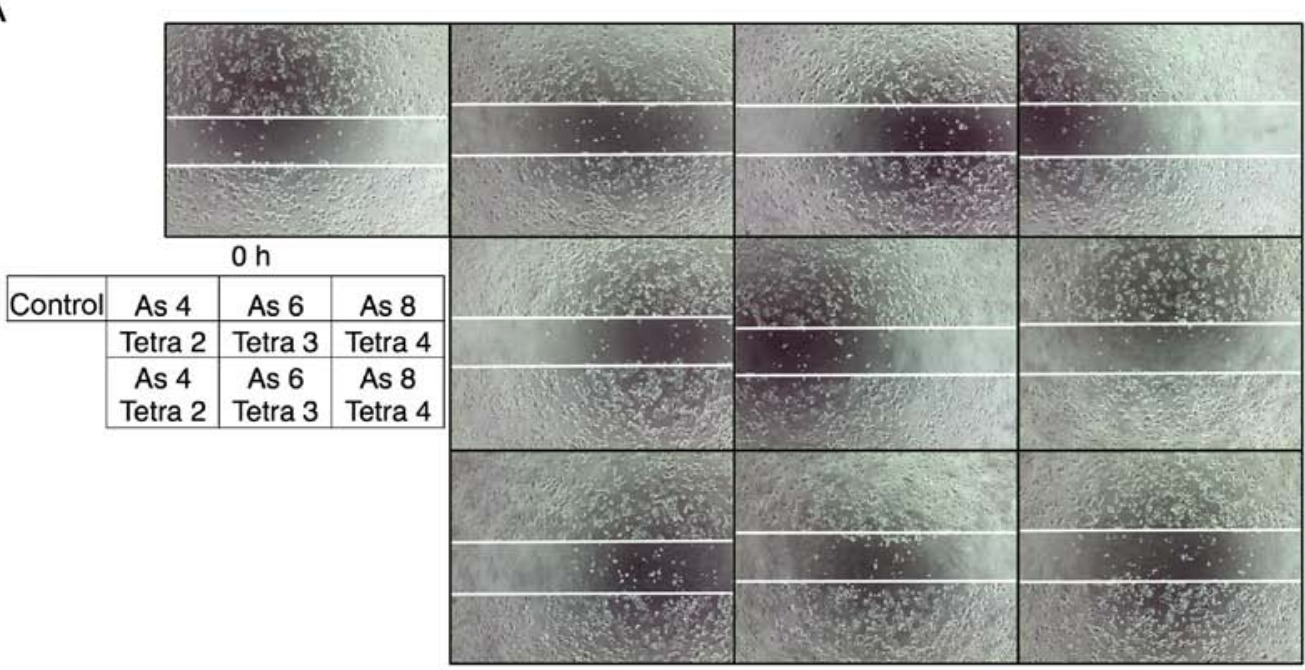

B

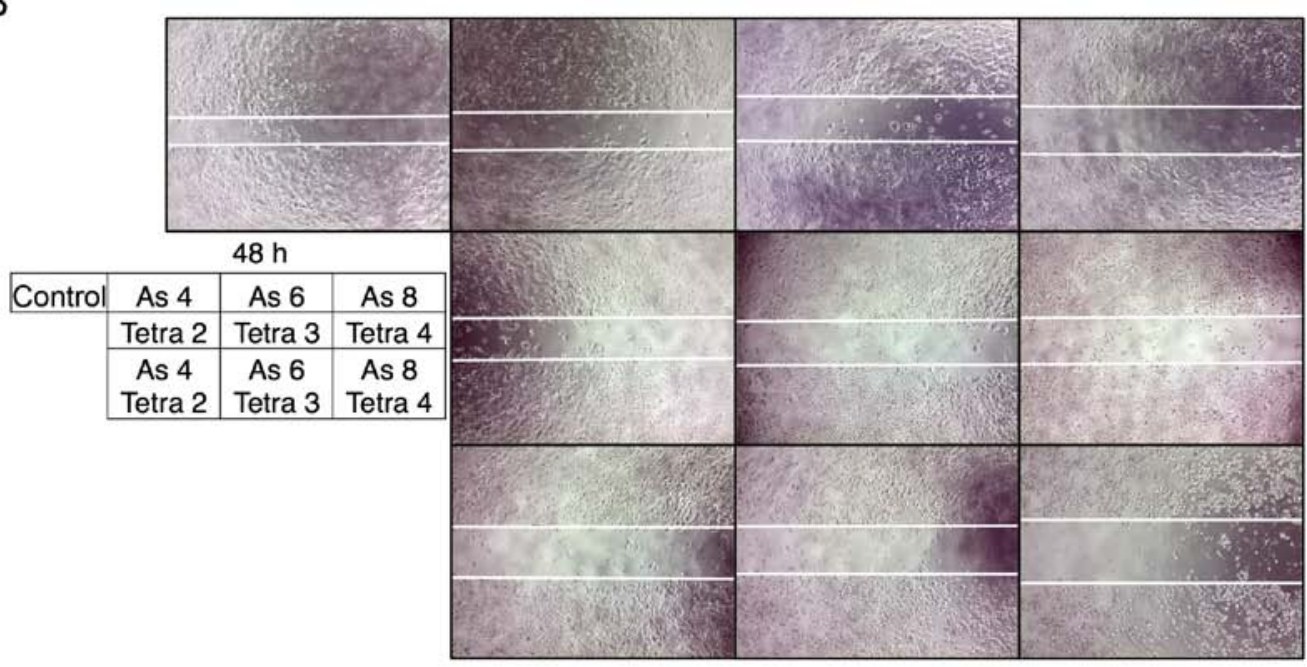

C

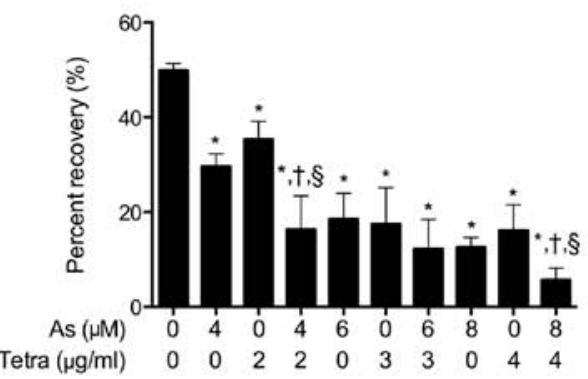

Figure 3. Inhibition of the migration ability of MCF-7 cells by As ${ }^{\mathrm{III}}$ in combination with Tetra. (A and B) Representative images of wound healing assays for cells treated with various concentrations of $\mathrm{As}^{\mathrm{III}}(4,6$ and $8 \mu \mathrm{M})$ and Tetra $(2,3$ and $4 \mu \mathrm{g} / \mathrm{ml})$, alone or in combination, for $48 \mathrm{~h}$. (C) The percent recovery as determined in the scratch wound healing assay. Data are presented as the means $\pm \mathrm{SD}$. ${ }^{*} \mathrm{P}<0.05 \mathrm{vs}$. control; ${ }^{\dagger} \mathrm{P}<0.05 \mathrm{vs}$. As ${ }^{\mathrm{III}}$ alone; ${ }^{\S} \mathrm{p}<0.05 \mathrm{vs}$. Tetra alone. Con, control (without drug treatment); As, As ${ }^{\mathrm{III}}$; Tetra, tetrandrine.

related-proteins in MCF-7 cells. To explore whether cell cycle arrest is involved in the cytotoxic effect of $\mathrm{As}^{\mathrm{III}}$ and Tetra, cell cycle analyses were performed using flow cytometry. As shown in Fig. 4A, after treatment with various concentrations of $\mathrm{As}{ }^{\mathrm{III}}$ and Tetra, alone or in combination, at $48 \mathrm{~h}$, a significant increase in the number of cells in $\mathrm{G}_{0} / \mathrm{G}_{1}$ phase was induced by As ${ }^{I I I}$ alone, but not by Tetra alone. Furthermore, a slight rise in the number of cells was found in the combination treatment compared to $\mathrm{As}^{\mathrm{III}}$ treatment alone. Concomitantly, a similar trend towards a decrease in the number of cells in $\mathrm{S}$ phase was also observed (Fig. 4B). As shown in Fig. 4C, in comparison to control group, the expression of FOXO3a was upregulated by $\mathrm{As}^{\mathrm{III}}$ and Tetra, each alone, and further strengthened by their combination. Noteworthy, the expression level of p21 was upregulated by $\mathrm{As}^{\mathrm{III}}$, and slightly enhanced by the addition of Tetra, although Tetra alone did not affect its expression level. The expression level of p27 was slightly increased by either $A s^{I I I}$ or Tetra alone compared to the control, and only a small enhancement in its expression was observed in the combined treatment group. Furthermore, a substantial decrease in the 
A

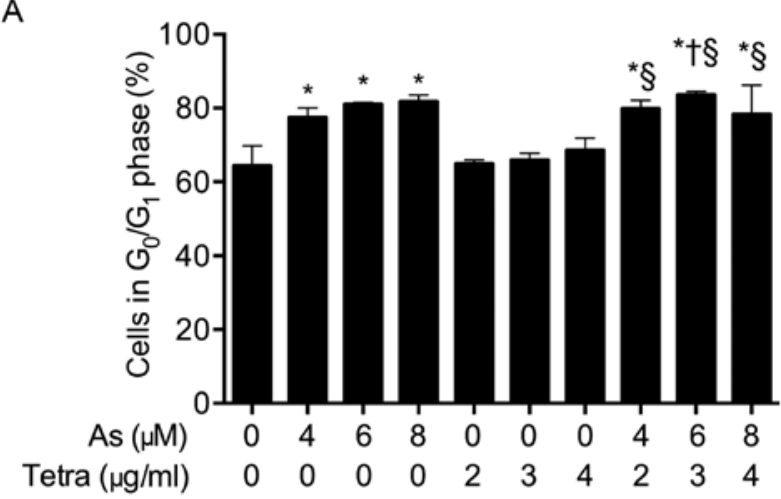

B

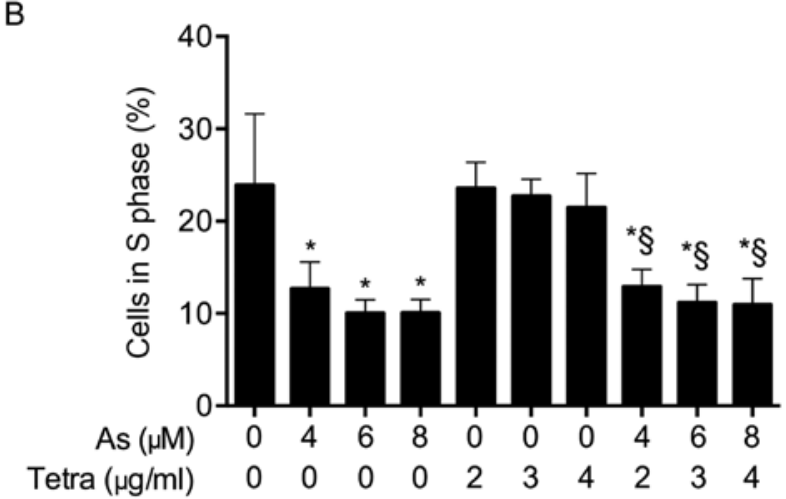

C

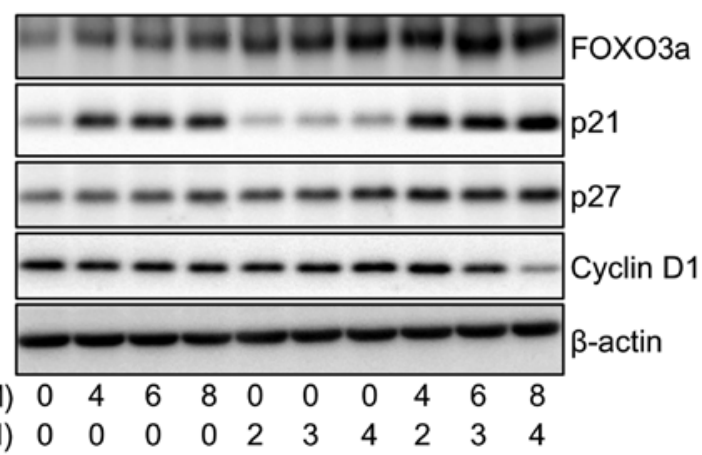

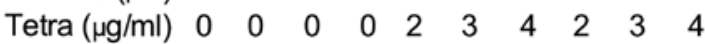

Figure 4. Effects of As ${ }^{\mathrm{III}}$ and Tetra, alone or in combination, on the cell cycle profiling and the expression level of cell cycle related-proteins in MCF-7 cells. After treatment with various concentrations of $\mathrm{As}^{\mathrm{III}}(4,6$ and $8 \mu \mathrm{M})$ and Tetra $(2,3$ and $4 \mu \mathrm{g} / \mathrm{ml})$, alone or in combination, for $48 \mathrm{~h}$, cell cycle analysis was performed using a FACSCanto flow cytometer (A and $\mathrm{B}$ ), and the expression profile of cell cycle-related proteins was analyzed using western blotting (C) as described in Materials and methods. Results are shown as the means \pm SD from three independent experiments. Significant difference between control and treatment with $\mathrm{As}^{\mathrm{III}}$ and Tetra are shown $\left({ }^{\mathrm{P}} \mathrm{P}<0.05\right.$ vs. control; ${ }^{\dagger} \mathrm{P}<0.05$ vs. As ${ }^{\mathrm{III}}$ alone; ${ }^{\mathrm{s}} \mathrm{p}<0.05$ vs. Tetra alone). Representative image of the expression profile of each protein is shown from three independent experiments. As, As ${ }^{\text {IIIF }}$ Tetra, tetrandrine.

expression level of cyclin D1 was observed in cells treated with the combination of $6 \mu \mathrm{M} \mathrm{As}^{\mathrm{III}}+3 \mu \mathrm{g} / \mathrm{ml}$ Tetra, and $8 \mu \mathrm{M} \mathrm{As}^{\mathrm{III}}$ $+4 \mu \mathrm{g} / \mathrm{ml}$ Tetra, respectively.

Synergistic effect between $A s^{I I I}$ and Tetra in inducing $L D H$ release in MCF-7 cells. After treatment with various concentrations of $\mathrm{As}^{\mathrm{III}}$ and Tetra, alone or in combination, for 48 and $72 \mathrm{~h}, \mathrm{LDH}$ leakage analysis was performed to examine whether the treatments affected cell membrane integrity. As
A

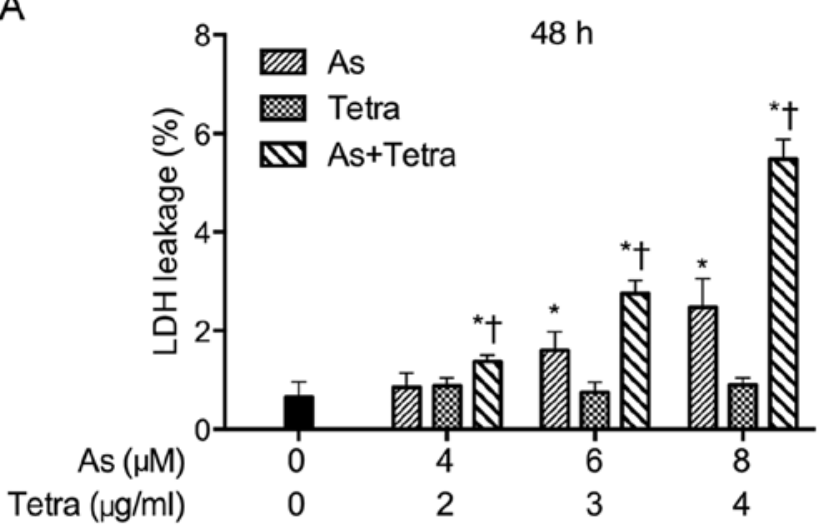

B

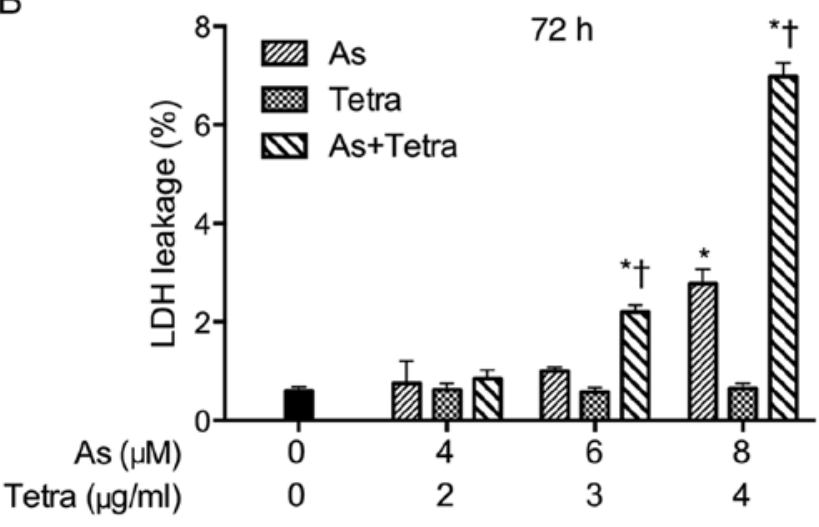

Figure 5. Synergistic effect between $\mathrm{As}^{\mathrm{III}}$ and Tetra in inducing LDH release in MCF-7 cells. After treatment with various concentrations of $\mathrm{As}^{\mathrm{III}}$ (4, 6 and $8 \mu \mathrm{M})$ and Tetra $(2,3$ and $4 \mu \mathrm{g} / \mathrm{ml})$, alone or in combination, for 48 (A) and $72 \mathrm{~h}$ (B), LDH leakage was measured using the LDH-Cytotoxic test kit as described in Materials and methods. Results are shown as the means \pm SD from three independent experiments. Significant difference between control and treatment with $\mathrm{As}^{\mathrm{III}}$ and Tetra are shown $\left({ }^{*} \mathrm{P}<0.05\right.$ vs. control; ${ }^{\dagger} \mathrm{P}<0.05$ vs. each alone). As, As ${ }^{\mathrm{III}}$; Tetra, tetrandrine.

shown in Fig. 5, a dose- and time-dependent LDH leakage was observed in MCF-7 cells treated with As ${ }^{\mathrm{III}}$ alone. Furthermore, the synergistic effect between $\mathrm{As}^{\mathrm{III}}$ and Tetra in inducing LDH leakage was observed during combination treatments, although only slight LDH leakage was detected in the cells treated with Tetra alone.

Activation of autophagic pathway in MCF-7 cells treated with $A s^{I I I}$ and Tetra, alone or in combination. Western blotting was performed to explore whether activation of an autophagic pathway occurred in MCF-7 cells after treatment with $\mathrm{As}^{\mathrm{III}}$ and Tetra, alone or in combination. As shown in Fig. 6, the expression level of LC3, an autophagic marker, was dramatically upregulated by Tetra. Although only a modest increase in the expression level of LC3 was observed when treated with $A s^{I I I}$ alone, the upregulation was further enhanced by their combination. In order to clarify the mechanisms underlying the signaling pathway activating autophagy, the expression of a several of autophagy-related proteins was evaluated. The expression levels of phosphorylated AMP-activated protein kinase (AMPK) (phospho-AMPK) were clearly upregulated by Tetra in a dose-dependent manner, while only a modest 


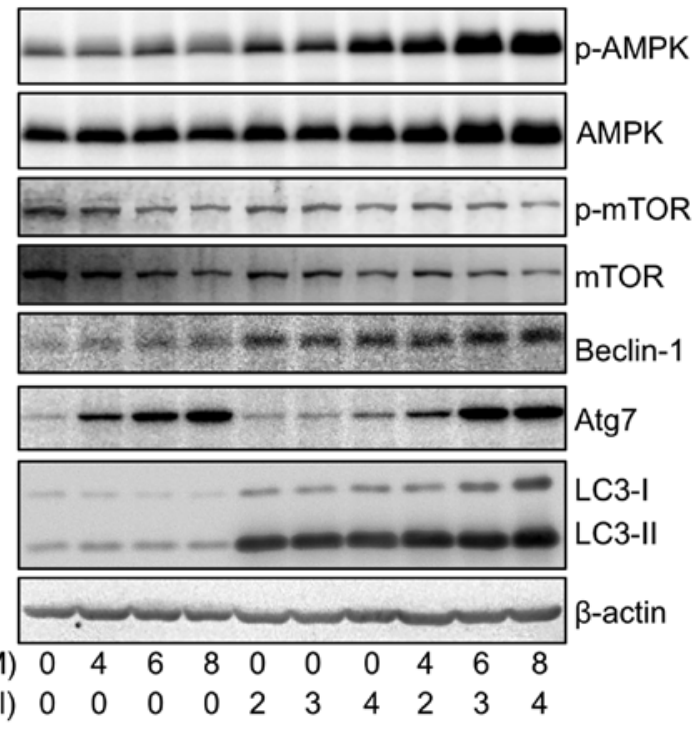

Figure 6. Expression profile of autophagy-related proteins in MCF-7 cells treated with As ${ }^{\mathrm{III}}$ and Tetra, alone or in combination. After treatment with various concentrations of $\mathrm{As}^{\mathrm{III}}(4,6$ and $8 \mu \mathrm{M})$ and Tetra $(2,3$ and $4 \mu \mathrm{g} / \mathrm{ml})$, alone or in combination, for $48 \mathrm{~h}$, the expression profile of autophagy-related proteins was analyzed using western blotting as described in Materials and methods. Representative image of the expression profile of each protein is shown from three independent experiments. As, $\mathrm{As}^{\mathrm{III}}$; Tetra, tetrandrine.

upregulation was observed when treated with As ${ }^{\mathrm{III}}$ alone. In comparison, a remarkable upregulation of phospho-AMPK as well as total-AMPK was observed in the cells treated with the combination treatment. Furthermore, the alteration of the expression levels of phosphorylated mammalian target of rapamycin (phospho-mTOR) and total-mTOR demonstrated an almost opposite behavior, showing a trend towards downregulation of their expression in the treated cells compared to controls. These results indicate that AMPK-mediated mTOR deactivation is involved during the autophagy induction. Similar to the alterations of the expression levels of phospho-AMPK, the expression levels of Beclin-1 were modestly and clearly upregulated in the cells treated with As ${ }^{\mathrm{III}}$, and Tetra, respectively, and the increment was further strengthened by the combinational treatment. Intriguingly, a dramatic increase in the expression level of Atg-7 was observed in $\mathrm{As}^{\mathrm{III}}$-treated cells, however, a modest increase in its expression was observed in Tetra-treated cells. Again, compared to the treatment with $\mathrm{As}^{\mathrm{III}}$ or Tetra alone, their combination treatment further enhanced the expression levels of Atg-7.

Expression profile of survivin gene in MCF-7 cells treated with As ${ }^{I I I}$ and Tetra, alone or in combination. After treatment with various concentrations of $\mathrm{As}^{\mathrm{III}}$ and Tetra, alone or in combination, for $48 \mathrm{~h}$, the expression profile of the survivin gene was analyzed using real-time PCR and western blotting. Treatment with a relatively high concentration of either $\mathrm{As}^{\mathrm{III}}(6$ and $8 \mu \mathrm{M})$ or Tetra $(4 \mu \mathrm{g} / \mathrm{ml})$ resulted in a significant decrease in the expression level of survivin mRNA (Fig. 7A). Similarly to the phenomena observed in proliferation inhibition and LDH leakage induced by As ${ }^{\mathrm{III}}$ and Tetra, a synergistic effect between $\mathrm{As}^{\mathrm{III}}$ and Tetra in suppressing the expression level of survivin mRNA was also observed (Fig. 7A).

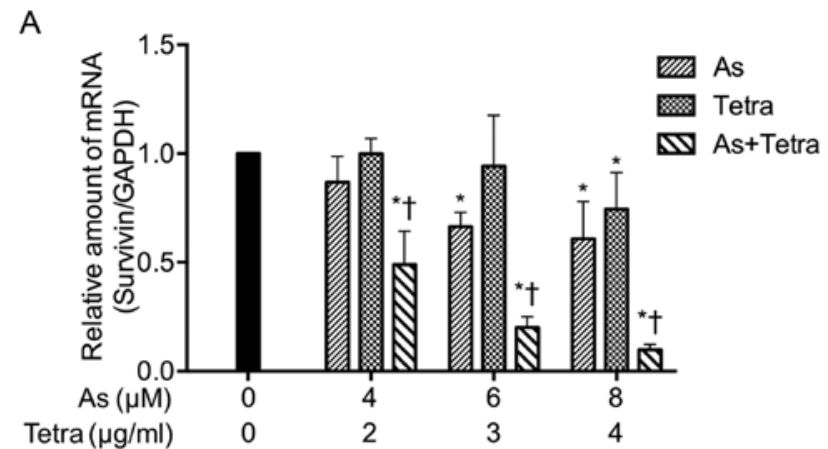

B

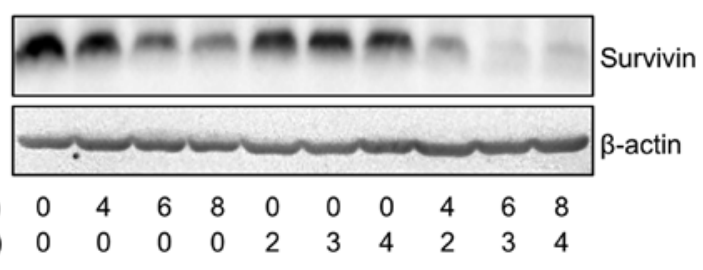

Figure 7. Expression profile of survivin gene in MCF-7 cells treated with $\mathrm{As}^{\mathrm{III}}$ and Tetra, alone or in combination. After treatment with various concentrations of $\mathrm{As}^{\mathrm{III}}(4,6$ and $8 \mu \mathrm{M})$ and Tetra $(2,3$ and $4 \mu \mathrm{g} / \mathrm{ml})$, alone or in combination, for $48 \mathrm{~h}$, the expression profile of survivin gene was analyzed using real-time PCR (A) and western blotting (B) as described in Materials and methods. Results are shown as the means \pm SD from three independent experiments. Representative image of the expression profile of survivin protein is shown from three independent experiments. Significant difference between control and treatment with $\mathrm{As}^{\mathrm{III}}$ and Tetra are shown $\left({ }^{*} \mathrm{P}<0.05\right.$ vs. control; ${ }^{\dagger} \mathrm{P}<0.05$ vs. each alone). As, $\mathrm{As}^{\mathrm{III}}{ }^{\text {; }}$ Tetra, tetrandrine.

Consistent with the expression profile of survivin mRNA, the synergistic effects in suppressing its protein expression level was further confirmed (Fig. 7B).

Enhanced As[i] along with synergistic cytotoxicity in MCF-7 cells treated with As ${ }^{I I I}$ combined with Tetra or Kol34. In order to clarify the correlation between synergistic cytotoxicity and As[i], arsenic uptake was first measured to examine whether Tetra affected As[i] in MCF-7 cells when combined with $\mathrm{As}^{\mathrm{III}}$. After exposure of MCF-7 cells to $3 \mu \mathrm{M} \mathrm{As}{ }^{\mathrm{III}}$ alone or in combination with $1 \mu \mathrm{g} / \mathrm{ml}$ Tetra for $0,1,2,4$ and $8 \mathrm{~h}$, As[i] was measured by ICP-MS. The levels of As[i] increased with time in the cells following treatment with $\mathrm{As}^{\mathrm{III}}$ alone (Fig. 8A). In comparison, Tetra in combination with $\mathrm{As}^{\mathrm{III}}$ further enhanced the levels of As[i] in the cells (Fig. 8A). Analogous augmentation in the levels of As[i] was also observed when treated with $\mathrm{As}^{\mathrm{III}}$ in combination with $2 \mu \mathrm{M}$ BCRP inhibitor Ko134 (Fig. 8B). In parallel, synergistic cytotoxicity was also observed in these combinational treatments (Fig. 8C and D), indicating the synergistic action of $\mathrm{As}{ }^{\mathrm{III}}$ and Tetra/Ko134 was attributed to the enhanced As[i].

\section{Discussion}

It has been demonstrated that $\mathrm{As}{ }^{\mathrm{III}}$ exhibits inhibitory effects on breast cancer cells (5-7), raising the possibility of utilizing arsenic compounds to treat patients with breast cancer. However, due to the lower susceptibility of solid tumors, including breast cancer, to arsenic compounds, there is a growing need to develop a novel therapeutic strategy aimed 
A

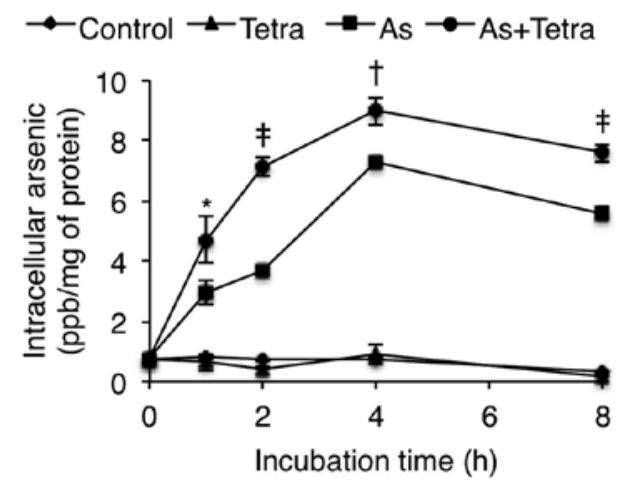

B

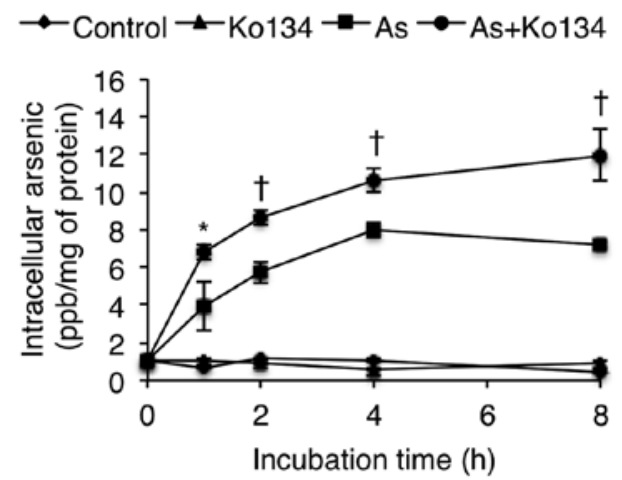

C

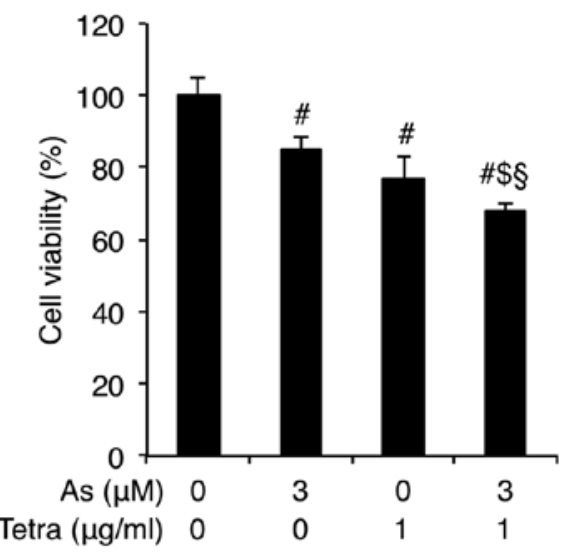

$\mathrm{D}$

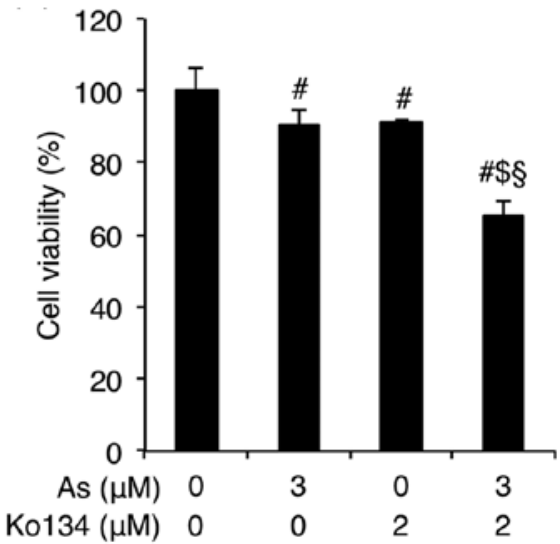

Figure 8. Enhanced As[i] along with synergistic cytotoxicity in MCF-7 cells treated with As ${ }^{\mathrm{III}}$ combined with Tetra or Ko134. After exposure of MCF-7 cells to $3 \mu \mathrm{M} \mathrm{As}{ }^{\mathrm{III}}$ alone or in combination with $1 \mu \mathrm{g} / \mathrm{ml}$ Tetra (A) or $2 \mu \mathrm{M}$ BCRP inhibitor Ko134 (B), respectively, for 0, 1, 2, 4 and $8 \mathrm{~h}$, As[i] was measured by ICP-MS, as described in Materials and methods. Furthermore, cell viability was determined by XTT assay after treatment with $3 \mu \mathrm{M}$ As ${ }^{\mathrm{III}}$ alone or in combination with $1 \mu \mathrm{g} / \mathrm{ml}$ Tetra (C) or $2 \mu \mathrm{M}$ BCRP inhibitor Ko134 (D), respectively, for $48 \mathrm{~h}$. Results are shown as the means \pm SD from three independent experiments. $\mathrm{P}<0.05$ was considered as statistically significant $\left({ }^{*} \mathrm{P}<0.05 ;{ }^{\dagger} \mathrm{P}<0.01\right.$ As vs. As+Tetra or As $+\mathrm{Ko} 134 ;{ }^{\dagger} \mathrm{P}<0.001 \mathrm{As}$ vs. As+Tetra; ${ }^{\sharp} \mathrm{P}<0.05$ vs. control; ${ }^{\$} \mathrm{P}<0.05$ vs. As alone; ${ }^{\S} \mathrm{P}<0.05$ vs. Tetra or Ko134 alone). As, $3 \mu \mathrm{M}$ As ${ }^{\mathrm{III}}$; Tetra, $1 \mu \mathrm{g} / \mathrm{ml}$ tetrandrine.

at improving its efficiency and reducing its side effects (8-10). Results from this study clearly demonstrate that Tetra significantly enhances the cytotoxicity of $\mathrm{As}^{\mathrm{III}}$ in MCF-7 cells in a synergistic manner as evidenced by the XTT assay, as well as inhibition of colony formation and migration of the cells (Figs. 1-3). Similarly, Tetra has been shown to augment the cytocidal effects of chemotherapeutic agents, including $\mathrm{As}^{\mathrm{III}}$, in different types of solid tumor cells $(13,14)$. While QT prolongation is a major complication in As ${ }^{\mathrm{III}}$ therapy (3), closely related to the intracellular $\left[\mathrm{Ca}^{2+}\right]$ overload induced by $\mathrm{As}^{\mathrm{III}}$ (42), Tetra, on the other hand, has been demonstrated to serve as a calcium channel antagonist significantly decreasing intracellular $\left[\mathrm{Ca}^{2+}\right]$ within ventricular cells (43). Collectively, the combination regimen of Tetra and $\mathrm{As}{ }^{\mathrm{III}}$ may be expected not only to achieve improved efficacy of As ${ }^{\mathrm{III}}$, but also overcome its adverse cardiac effects secondary to Tetra functioning as calcium channel blocker (44).

Cell cycle arrest, necrosis, as well as autophagic cell death have all been viewed as the major underlying mechanisms for the cytocidal effects of most drugs used against tumors $(7,13,15-18)$. To examine the probable mechanisms underlying the cytocidal effect of the combination of $\mathrm{As}^{\mathrm{III}}$ and Tetra, cell cycle arrest was first examined in MCF-7 cells treated with $A s^{\mathrm{III}}$ and Tetra, alone or in combination. A clear $\mathrm{G}_{0} / \mathrm{G}_{1}$ cell cycle arrest was observed when treated with $\mathrm{As}{ }^{\mathrm{III}}$ alone, and was slightly strengthened by the addition of Tetra (Fig. 4A). These findings are supported by previous studies showing that As ${ }^{\mathrm{III}}$ inhibits the cellular proliferation of MCF-7 cells via a $\mathrm{G}_{1}$ and/or $\mathrm{G}_{2} / \mathrm{M}$ phase arrest $(7,45)$. We further demonstrated that the expression level of FOXO3a, was upregulated by $\mathrm{As}^{\mathrm{III}}$ and Tetra, both alone and then further enhanced by their combination (Fig. 4C).

FOXO3a has been implicated in cell cycle arrest leading to growth inhibition via upregulation of p21, p27 and downregulation of cyclin D1 in various cancers including breast cancer (2,20-22). In line with these previous findings, a concomitant increase and decrease in the expression levels of p21, p27, and cycline D1, respectively, was observed in MCF-7 cells treated with As ${ }^{\mathrm{III}}$ and/or Tetra, although a synergistic effect on the alteration of each gene was not clear in the combined treatment group (Fig. 4C). We have also noted that the magnitude of cell cycle arrest does not completely correlate to the degree of alterations in the expression level of the above-mentioned cell cycle arrest-related genes. In this regard, besides contributing to cell cycle arrest, upregulation of FOXO3a expression is known to inhibit migration and 
invasion of different types of solid tumors such as gastric and renal cancer through inactivating epithelial-mesenchymal transition (EMT) of cancer cells as a result of downregulation of SNAIL1, a key regulator of EMT $(23,24)$. Therefore, our results suggest that the alterations of $\mathrm{FOXO} 3 \mathrm{a}$ along with $\mathrm{p} 21$, p27, cyclin D1 are responsible for not only $G_{0} / G_{1}$ cell cycle arrest but also migration inhibition of MCF-7 cells induced by $\mathrm{As}^{\mathrm{III}}$ and/or Tetra, although a more thorough analysis must be performed to confirm this correlation.

We further demonstrated that combining Tetra with As ${ }^{\mathrm{III}}$ synergistically induced LDH release in MCF-7 cells (Fig. 5). Since the release of $\mathrm{LDH}$ provides an accurate measure of the cell membrane integrity and cell viability $(15,33)$, our results suggest the involvement of necrotic cell death in the synergistic action of the combination. $A s^{\mathrm{III}}$ has been demonstrated to induce necrotic cell death through a regulated, Bcl-xL-sensitive mitochondrial pathway that is largely caspase-independent, providing a plausible explanation for its capability of triggering cell death in a variety of drugresistant cell types including tumor cells even with defects in caspase activation (46).

Induction of autophagy by various anticancer drugs has also been suggested as a potential therapeutic strategy for cancer $(16,25,47,48)$. In this respect, Tetra is known to function as a potent agonist for cell autophagy in numerous cancer cells including breast cancer cells $(47,49)$. Moreover, autophagy has been demonstrated to partially contribute to

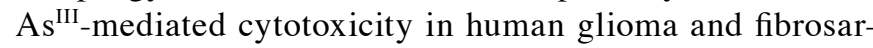
coma cells in vitro and in vivo $(25,50)$. In line with previous reports, autophagy induction was clearly observed in MCF-7 cells treated with As ${ }^{\mathrm{III}}$ and Tetra, alone or in combination, as evidenced by the marked increase in expression levels of LC3, an autophagic marker $(16,47,48)$, along with the activation of the autophagic pathway involving a number of important molecules including phospho-AMPK, Beclin-1, and Atg-7 (Fig. 6). It is well known that AMPK is key energy sensor and an upstream promoter of autophagy induction (22), and that Beclin-1 is an autophagic mediator which is deleted in $50 \%$ of breast tumors $(18,51)$. Atg-7 is also known as a key player in autophagosomes formation and to be involved in plant-derived polyphenol-mediated autophagic cell death in breast cancer cells (48). Our results suggest that the synergistic cytotoxic effect of $\mathrm{As}{ }^{\mathrm{III}}$ and Tetra against MCF-7 cells should be attributed to $G_{0} / G_{1}$ cell cycle arrest, $L D H$ leakage, and autophagy induction.

The cancer-associated protein survivin is highly expressed in most human tumor cell lines, in particular breast and lung cancer cell lines (52). Therefore, the inhibition of survivin has been pursued as a compelling strategy for cancer therapy (53). Besides its critical role in apoptosis inhibition, survivin is also known to regulate cell cycle arrest and autophagy (25-28). Lee et al have demonstrated that suberoylanilide hydroxamic acid (SAHA), a novel histone deacetylase inhibitor, induces autophagy and cell viability reduction in human breast cancer cells by downregulating the expression of survivin, as a result of inducing survivin protein acetylation and impairing its stability (26). Chiu et al also demonstrated that $\mathrm{As}^{\mathrm{III}}$-induced autophagy was paralleled by the downregulation of survivin in human glioma cells in vitro and in vivo (25). In this study, the synergistic inhibitory effect of $\mathrm{As}^{\mathrm{III}}$ and Tetra on the expression levels of survivin was observed (Fig. 7). Taking the previous results and our observations into account, we suggest that survivin plays a vital role in the cytocidal effects of the combined regimen of $\mathrm{As}^{\mathrm{III}}$ plus Tetra, leading to potentially new options for the combination therapy in patients with breast cancer.

Since drug action usually requires uptake of the drug, it was considered that As[i] might determine the sensitivity of cancer cells to arsenic compounds (3). Enhanced As[i] along with synergistic cytotoxicity was observed in our experiments, suggesting a positive correlation between synergistic cytotoxicity of combination treatment and enhanced As[i] in MCF-7 cells. Wang et al (31) have demonstrated that Tetra enhances cytotoxicity of cisplatin in human drug-resistant esophageal squamous carcinoma cells by inhibition of MRP1, which is also known to be involved in the efflux of $\mathrm{As}^{\mathrm{III}}$ (3). We previously demonstrated that Tetra can serve as a potent inhibitor of MDR1 (also known as P-glycoprotein, P-gp) to reverse multidrug resistance to anticancer drugs such as daunorubicin, vinblastine and doxorubicin in a human $\mathrm{T}$ lymphoblastoid leukemia MOLT-4 MDR cell line (30), although the roles of P-gp in arsenic efflux remain controversial (3). Despite the fact that BCRP is known to mediate concurrent resistance to chemotherapeutic agents including mitoxantrone, doxorubicin, and daunorubicin in MCF-7/AdrVp, a multidrugresistant human breast cancer subline (54), its relevance for resistance to arsenic is unknown. By demonstrating the enhanced As[i] along with the synergistic cytotoxicity in MCF-7 cells when treated with As ${ }^{\text {III }}$ combined with Ko134, this suggests for the first time the possibility of manipulating BCRP to overcome the resistance to the arsenic-based regimens, although a previous study reported that BCRPoverexpressing MDA-MB-231-BCRP cells were not more resistant to As ${ }^{\mathrm{III}}$ than their drug-sensitive counterparts (55). Therefore, further studies need to be launched in order to draw a solid conclusion about the involvement of BCRP in arsenic resistance. Collectively, our results imply that Tetra and/or BCRP inhibitor probably intervene in the occurrence of resistance to arsenic therapy by enhancing the As[i] via modulation of multidrug efflux transporters such as MRP1, P-gp, and BCRP.

Our results suggest that Tetra can be a useful combination anticancer agent to enhance the therapeutic effect of As ${ }^{\text {III }}$ for patients with breast cancer by enhancing the As[i] and consequently strengthening $\mathrm{As} \mathrm{s}^{\mathrm{III}}$-mediated growth inhibition associated with cell cycle arrest, necrosis, and autophagic cell death, all of which seemed to be related to the downregulation of survivin. Therefore, these results may provide a rational molecular basis for the combination regimen of $\mathrm{As}{ }^{\mathrm{III}}$ plus Tetra, facilitating the development of As ${ }^{\text {III-based anticancer }}$ strategies or combination therapies for patients with solid tumors, especially breast cancer.

\section{Acknowledgements}

We deeply thank Associate Professor Marcus Ferrone of University of California, San Francisco (UCSF) School of Pharmacy for the critical reading of this manuscript. This work was supported by The Japan Society for the Promotion of Science (JSPS) KAKENHI Grant to B.Y. (grant no. 26460233). 


\section{References}

1. Siegel R, Naishadham D and Jemal A: Cancer statistics, 2013. CA Cancer J Clin 63: 11-30, 2013.

2. Taylor S, Lam M, Pararasa C, Brown JE, Carmichael AR and Griffiths HR: Evaluating the evidence for targeting FOXO3a in breast cancer: A systematic review. Cancer Cell Int 15: 1, 2015.

3. Yuan B, Yoshino Y, Kaise T and Toyoda H: Application of arsenic trioxide therapy for patients with leukemia. In: Biological Chemistry of Arsenic, Antimony and Bismuth. Sun H (ed). John Wiley \& Sons, Ltd., Chichester, pp263-292, 2011.

4. Dilda PJ and Hogg PJ: Arsenical-based cancer drugs. Cancer Treat Rev 33: 542-564, 2007.

5. Chow SK, Chan JY and Fung KP: Suppression of cell proliferation and regulation of estrogen receptor alpha signaling pathway by arsenic trioxide on human breast cancer MCF-7 cells. J Endocrinol 182: 325-337, 2004.

6. Liu W, Gong Y, Li H, Jiang G, Zhan S, Liu H and Wu Y: Arsenic trioxide-induced growth arrest of breast cancer MCF-7 cells involving $\mathrm{FOXO} 3 \mathrm{a}$ and $\mathrm{I \kappa \textrm {B }}$ kinase $\beta$ expression and localization. Cancer Biother Radiopharm 27: 504-512, 2012.

7. Wang X, Gao P, Long M, Lin F, Wei JX, Ren JH, Yan L, He T, Han Y and Zhang HZ: Essential role of cell cycle regulatory genes p21 and p27 expression in inhibition of breast cancer cells by arsenic trioxide. Med Oncol 28: 1225-1254, 2011.

8. Kasukabe T, Okabe-Kado J, Kato N, Honma Y and Kumakura S: Cotylenin A and arsenic trioxide cooperatively suppress cell proliferation and cell invasion activity in human breast cancer cells. Int J Oncol 46: 841-848, 2015.

9. Lin CC, Hsu C, Hsu CH, Hsu WL, Cheng AL and Yang CH: Arsenic trioxide in patients with hepatocellular carcinoma: A phase II trial. Invest New Drugs 25: 77-84, 2007.

10. Vuky J, Yu R, Schwartz L and Motzer RJ: Phase II trial of arsenic trioxide in patients with metastatic renal cell carcinoma. Invest New Drugs 20: 327-330, 2002.

11. Liu T, Liu X and Li W: Tetrandrine, a Chinese plant-derived alkaloid, is a potential candidate for cancer chemotherapy. Oncotarget 7: 40800-40815, 2016.

12. Fu LW, Zhang YM, Liang YJ, Yang XP and Pan QC: The multidrug resistance of tumour cells was reversed by tetrandrine in vitro and in xenografts derived from human breast adenocarcinoma MCF-7/adr cells. Eur J Cancer 38: 418-426, 2002.

13. Chen Y, Li P, Yang S, Tong N, Zhang J and Zhao X: Tetrandrine enhances the anticancer effects of arsenic trioxide in vitro. Int $\mathrm{J}$ Clin Pharmacol Ther 52: 416-424, 2014.

14. Wei J, Liu B, Wang L, Qian X, Ding Y and Yu L: Synergistic interaction between tetrandrine and chemotherapeutic agents and influence of tetrandrine on chemotherapeutic agent-associated genes in human gastric cancer cell lines. Cancer Chemother Pharmacol 60: 703-711, 2007.

15. Kon A, Yuan B, Hanazawa T, Kikuchi H, Sato M, Furutani R, Takagi $\mathrm{N}$ and Toyoda $\mathrm{H}$ : Contribution of membrane progesterone receptor $\alpha$ to the induction of progesterone-mediated apoptosis associated with mitochondrial membrane disruption and caspase cascade activation in Jurkat cell lines. Oncol Rep 30: 1965-1970, 2013.

16. Wang X, Qi W, Li Y, Zhang N, Dong L, Sun M, Cun J, Zhang Y, Lv S and Yang Q: Huaier extract induces autophagic cell death by inhibiting the mTOR/S6K pathway in breast cancer cells. PLoS One 10: e0131771, 2015.

17. Yuan B, Okusumi S, Yoshino Y, Moriyama C, Tanaka S, Hirano T, Takagi N and Toyoda H: Delphinidin induces cytotoxicity and potentiates cytocidal effect in combination with arsenite in an acute promyelocytic leukemia NB4 cell line. Oncol Rep 34: 431-438, 2015.

18. Chen $\mathrm{N}$ and Karantza-Wadsworth V: Role and regulation of autophagy in cancer. Biochim Biophys Acta 1793: 1516-1523, 2009.

19. Mei L, Chen Y, Wang Z, Wang J, Wan J, Yu C, Liu X and Li W: Synergistic anti-tumour effects of tetrandrine and chloroquine combination therapy in human cancer: A potential antagonistic role for $\mathrm{p} 21$. Br J Pharmacol 172: 2232-2245, 2015.

20. Lin CH, Chang CY, Lee KR, Lin HJ, Chen TH and Wan L: Flavones inhibit breast cancer proliferation through the Akt/ FOXO3a signaling pathway. BMC Cancer 15: 958, 2015.

21. Jiang Y, Zou L, Lu WQ, Zhang Y and Shen AG: Foxo3a expression is a prognostic marker in breast cancer. PLoS One 8: e70746, 2013.

22. Chiacchiera F and Simone C: The AMPK-FoxO3A axis as a target for cancer treatment. Cell Cycle 9: 1091-1096, 2010.
23. Li Y, Fu LX, Zhu WL, Shi H, Chen LJ and Ye B: Blockade of CXCR6 reduces invasive potential of gastric cancer cells through inhibition of AKT signaling. Int J Immunopathol Pharmacol 28: 194-200, 2015.

24. Ni D, Ma X, Li HZ, Gao Y, Li XT, Zhang Y, Ai Q, Zhang P, Song EL, Huang QB, et al: Downregulation of FOXO3a promotes tumor metastasis and is associated with metastasis-free survival of patients with clear cell renal cell carcinoma. Clin Cancer Res 20: 1779-1790, 2014.

25. Chiu HW, Ho YS and Wang YJ: Arsenic trioxide induces autophagy and apoptosis in human glioma cells in vitro and in vivo through downregulation of survivin. J Mol Med (Berl) 89: 927-941, 2011.

26. Lee JY, Kuo CW, Tsai SL, Cheng SM, Chen SH, Chan HH, Lin CH, Lin KY, Li CF, Kanwar JR, et al: Inhibition of HDAC3and HDAC6-promoted survivin expression plays an important role in SAHA-induced autophagy and viability reduction in breast cancer cells. Front Pharmacol 7: 81, 2016.

27. Li Y, Liu D, Zhou Y, Li Y, Xie J, Lee RJ, Cai Y and Teng L: Silencing of survivin expression leads to reduced proliferation and cell cycle arrest in cancer cells. J Cancer 6: 1187-1194, 2015.

28. Liu W, Zhu F, Jiang Y, Sun D, Yang B and Yan H: siRNA targeting survivin inhibits the growth and enhances the chemosensitivity of hepatocellular carcinoma cells. Oncol Rep 29: 1183-1188, 2013.

29. Early Breast Cancer Trialists' Collaborative Group (EBCTCG): Effects of chemotherapy and hormonal therapy for early breast cancer on recurrence and 15-year survival: An overview of the randomised trials. Lancet 365: 1687-1717, 2005.

30. Liu ZL, Hirano T, Tanaka S, Onda K and Oka K: Persistent reversal of P-glycoprotein-mediated daunorubicin resistance by tetrandrine in multidrug-resistant human $\mathrm{T}$ lymphoblastoid leukemia MOLT-4 cells. J Pharm Pharmacol 55: 1531-1537, 2003.

31. Wang TH, Wan JY, Gong X, Li HZ and Cheng Y: Tetrandrine enhances cytotoxicity of cisplatin in human drug-resistant esophageal squamous carcinoma cells by inhibition of multidrug resistance-associated protein 1. Oncol Rep 28: 1681-1686, 2012.

32. Wang YS, Zhou ST and Wei HL: Apoptosis effects of drug sensitivity leukemia cells induced by nano-realgar. Zhongguo Zhong Yao Za Zhi 38: 2202-2205, 2013 (In Chinese).

33. Yoshino Y, Yuan B, Kaise T, Takeichi M, Tanaka S, Hirano T, Kroetz DL and Toyoda H: Contribution of aquaporin 9 and multidrug resistance-associated protein 2 to differential sensitivity to arsenite between primary cultured chorion and amnion cells prepared from human fetal membranes. Toxicol Appl Pharmacol 257: 198-208, 2011.

34. Chou TC: Drug combination studies and their synergy quantification using the Chou-Talalay method. Cancer Res 70: 440-446, 2010.

35. Chou TC: Theoretical basis, experimental design, and computerized simulation of synergism and antagonism in drug combination studies. Pharmacol Rev 58: 621-681, 2006.

36. El-Aarag BY, Kasai T, Zahran MA, Zakhary NI, Shigehiro T, Sekhar SC, Agwa HS, Mizutani A, Murakami H, Kakuta H, et al: In vitro anti-proliferative and anti-angiogenic activities of thalidomide dithiocarbamate analogs. Int Immunopharmacol 21: 283-292, 2014.

37. Kikuchi H, Yuan B, Yuhara E, Takagi N and Toyoda H: Involvement of histone $\mathrm{H} 3$ phosphorylation through p38 MAPK pathway activation in casticin-induced cytocidal effects against the human promyelocytic cell line HL-60. Int J Oncol 43: 2046-2056, 2013.

38. Kikuchi H, Yuan B, Yuhara E, Imai M, Furutani R, Fukushima S, Hazama S, Hirobe C, Ohyama K, Takagi N, et al: Involvement of histone $\mathrm{H} 3$ phosphorylation via the activation of p38 MAPK pathway and intracellular redox status in cytotoxicity of HL-60 cells induced by Vitex agnus-castus fruit extract. Int J Oncol 45: 843-852, 2014

39. Zekri A, Ghaffari SH, Yousefi M, Ghanizadeh-Vesali S, Mojarrad M, Alimoghaddam K and Ghavamzadeh A: Autocrine human growth hormone increases sensitivity of mammary carcinoma cell to arsenic trioxide-induced apoptosis. Mol Cell Endocrinol 377: 84-92, 2013.

40. Yuan B, Ohyama K, Takeichi M and Toyoda H: Direct contribution of inducible nitric oxide synthase expression to apoptosis induction in primary smooth chorion trophoblast cells of human fetal membrane tissues. Int J Biochem Cell Biol 41: 1062-1069, 2009. 
41. Yoshino Y, Yuan B, Miyashita SI, Iriyama N, Horikoshi A Shikino O, Toyoda $\mathrm{H}$ and Kaise T: Speciation of arsenic trioxide metabolites in blood cells and plasma of a patient with acute promyelocytic leukemia. Anal Bioanal Chem 393: 689-697, 2009.

42. Zhang Y, Dong Z, Jin L, Zhang K, Zhao X, Fu J, Gong Y, Sun M, Yang B and Li B: Arsenic trioxide-induced hERG K(+) channel deficiency can be rescued by matrine and oxymatrine through up-regulating transcription factor Sp1 expression. Biochem Pharmacol 85: 59-68, 2013.

43. Liu QY, Karpinski E and Pang PK: Tetrandrine inhibits both T and $\mathrm{L}$ calcium channel currents in ventricular cells. J Cardiovasc Pharmacol 20: 513-519, 1992.

44. Ficker E, Kuryshev YA, Dennis AT, Obejero-Paz C, Wang L, Hawryluk P, Wible BA and Brown AM: Mechanisms of arsenicinduced prolongation of cardiac repolarization. Mol Pharmacol 66: 33-44, 2004.

45. Chow SK, Chan JY and Fung KP: Inhibition of cell proliferation and the action mechanisms of arsenic trioxide $\left(\mathrm{As}_{2} \mathrm{O}_{3}\right)$ on human breast cancer cells. J Cell Biochem 93: 173-187, 2004

46. Scholz C, Wieder T, Stärck L, Essmann F, Schulze-Osthoff K Dörken B and Daniel PT: Arsenic trioxide triggers a regulated form of caspase-independent necrotic cell death via the mitochondrial death pathway. Oncogene 24: 1904-1913, 2005.

47. Liu T, Men Q, Wu G, Yu C, Huang Z, Liu X and Li W: Tetrandrine induces autophagy and differentiation by activating ROS and Notch1 signaling in leukemia cells. Oncotarget 6: 7992-8006, 2015.

48. Zhang L, Shamaladevi N, Jayaprakasha GK, Patil BS and Lokeshwar BL: Polyphenol-rich extract of Pimenta dioica berries (Allspice) kills breast cancer cells by autophagy and delays growth of triple negative breast cancer in athymic mice. Oncotarget 6: 16379-16395, 2015.
49. Wang H, Liu T, Li L, Wang Q, Yu C, Liu X and Li W: Tetrandrine is a potent cell autophagy agonist via activated intracellular reactive oxygen species. Cell Biosci 5: 4, 2015.

50. Chiu HW, Lin JH, Chen YA, Ho SY and Wang YJ: Combination treatment with arsenic trioxide and irradiation enhances cellkilling effects in human fibrosarcoma cells in vitro and in vivo through induction of both autophagy and apoptosis. Autophagy 6: $353-365,2010$

51. Tsai JH, Hsu LS, Huang HC, Lin CL, Pan MH, Hong HM and Chen WJ: 1-(2-Hydroxy-5-methylphenyl)-3-phenyl-1,3propanedione induces G1 cell cycle arrest and autophagy in HeLa cervical cancer cells. Int J Mol Sci 17: 17, 2016.

52. Tamm I, Wang Y, Sausville E, Scudiero DA, Vigna N, Oltersdorf T and Reed JC: IAP-family protein survivin inhibits caspase activity and apoptosis induced by Fas (CD95), Bax, caspases, and anticancer drugs. Cancer Res 58: 5315-5320, 1998.

53. Chen X, Duan N, Zhang C and Zhang W: Survivin and tumorigenesis: Molecular mechanisms and therapeutic strategies. J Cancer 7: 314-323, 2016.

54. Doyle LA, Yang W, Abruzzo LV, Krogmann T, Gao Y, Rishi AK and Ross DD: A multidrug resistance transporter from human MCF-7 breast cancer cells. Proc Natl Acad Sci USA 95: 15665-15670, 1998.

55. Sertel S, Tome M, Briehl MM, Bauer J, Hock K, Plinkert PK and Efferth T: Factors determining sensitivity and resistance of tumor cells to arsenic trioxide. PLoS One 7: e35584, 2012. 